\title{
Clonal structure of Trypa nosoma cruzi Colombian strain (biodeme Type III): biological, isoenzymic and histopathological analysis of seven isolated clones
}

\author{
Estrutura clonal da cepa Colombiana do Trypanosoma cruzi (Biodema Tipo III): análise \\ biológica, isoenzimática ehistopatológica de sete clones isolados
}

\author{
Edson Luiz Paes Camandaroba', Rozália Figueira Campos ${ }^{2}$, Juracy Barbosa Magalhães ${ }^{1}$ \\ and Sonia G. Andrade ${ }^{1}$
}

\begin{abstract}
The clonal structure of the Colombian strain of Trypanosoma cruzi, biodeme Type III and zymodeme 1, was analyzed in order to characterize its populations and to establish its homogeneity or heterogeneity. Seven isolated clones presented the basic characteristics of Biodeme Type III, with the same patterns of parasitemic curves, tissue tropism to skeletal muscle and myocardium, high pathogenicity with extensive necrotic-inflammatory lesions from the $20^{\text {th }}$ to $30^{\text {th }}$ day of infection. The parental strain and its clones C1, C3, C4 and C6, determined the higher levels of parasitemia, 20 to 30 days of infection, with high mortality rate up to 30 days (79 to $100 \%$ ); clones C2, C5 and C7 presented lower levels of parasitemia, with low mortality rates (7.6 to 23\%). Isoenzymic patterns, characteristic of zymodeme 1, (Z1) were similar for the parental strain and its seven clones. Results point to a phenotypic homogeneity of the clones isolated from the Colombian strain and suggest the predominance of a principal clone, responsible for the biological behavior of the parental strain and clones.
\end{abstract}

Key-words: Trypanosoma cruzi. Colombian strain. Clonal structure. Clones. Biodemes. Zymodemes. Histopathology.

Resumo A estrutura clonal da cepa Colombiana do Trypanosoma cruzi, biodema Tipo III e zimodema 1, foi analisada com o objetivo de caracterizar as suas populações e estabelecer a homogeneidade ou heterogeneidade das mesmas. Foram isolados sete clones, os quais apresentaram as características básicas do biodema Tipo III, com o mesmo padrão de curvas parasitêmicas, tropismo tecidual para músculo esquelético e miocárdio, alta patogenicidade, com extensas lesões necrótico-inflamatórias, do $20^{\circ}$ ao $30^{\circ}$ dia de infecção. A cepa parental e os clones C1, C3, C4 e C6 apresentaram os niveis mais elevados de parasitemia entre 20 e 30 dias pós-infecção e alto indice de mortalidade até 30 dias (79 a 100\%); os clones C2, C5 e C7 apresentaram niveis mais baixos de parasitemia com baixa mortalidade até 30 dias $(7,6$ a $23 \%)$. Os padrões isoenzimáticos foram característicos do zimodema 1 (Z1) para a cepa parental e os sete clones. Os achados do presente trabalho indicam uma homogeneidade fenotípica entre os clones isolados da cepa Colombiana e sugerem a predominância de um clone principal, responsável pelo padrão de comportamento biológico da cepa parental e dos clones.

Palavras-chaves: Trypanosoma cruzi. Cepa Colombiana. Estrutura clonal. Clones. Biodemas Zimodemas. Histopatologia.

The Colombian strain of $T$. cruzi has been used in experimental investigations since the pioneering studies of Federici et $a^{12}$. They described the progressive myocarditis occurring in mice as well as the main features of chronic disease in the murine model. Comparative studies of the biological behavior and histopathological lesions produced by the Colombian, $\mathrm{Y}^{17}$ and São Felipe strains ${ }^{1}$ showed marked differences in tissue tropism, virulence and pathogenicity ${ }^{3}$. These strains came to represent the prototypes for three different biological types or biodemes: I, II, III. The Colombian strain was isolated from a human case originating in Colombia ${ }^{12}$ and was typed as Biodeme Type III and identified as zymodeme Z1 by Andrade et $a \Gamma^{\top}$, according to the isoenzymic patterns of Miles et $a l^{14}$. This classification corresponds to the recently

1. Laboratório de Doença de Chagas Experimental do Centro de Pesquisas Gonçalo Moniz/Fundação Instituto Oswaldo Cruz (FIOCRUZ). Salvador, BA. 2. Departamento de Ciências Biológicas, Universidade Estadual de Feira de Santana, Feira de Santana, BA.

Financial support - PAPES II - FIOCRUZ, Rio de Janeiro, RJ.

Address to: Dra. Sonia G. Andrade. Centro de Pesquisas Gonçalo Moniz /FIOCRUZ. R. Valdemar Falcão 121, Brotas 41945-001 Salvador, BA. Fax: 5571 356-2155.

e-mail: sgandrade@ cpqgm.fiocruz.br

Recebido para publicação em 3/7/2000. 
established taxa T. cruzil, as referred by Momem ${ }^{15}$. Another characteristic of Biodeme Type III is its resistance to chemotherapy with benznidazole and nifurtimox ${ }^{4}$.

Since T. cruzi strains represent multiclonal populations ${ }^{18}$, investigation of their structure should contribute to define the homogeneity or heterogeneity of its clonal constitution. This seems crucial to clarify a possible role of parasite strains in the clinical manifestations of Chagas' disease. Inasmuch the possibility of a predominance of principal clones, as representative of strains circulating in one endemic area, has been recently suggested ${ }^{2} 910$.

\section{MATERIALS AND METHODS}

T. cruzi strain. The Colombian strain, maintained in our Laboratory by successive passages into mice for several years, has been used in the present investigation. Cloning of the strain. To obtain a single parasite, citrated blood taken from mice infected with the parental strain, on the $30^{\text {th }}$ day of infection, was centrifuged at $900 \mathrm{~g}$ and parasites in the plasma counted in a Neubauer chamber after dilution in PBS, $\mathrm{pH}$ 7.2. The volume of $1 \mathrm{ml}$ was distributed in multi-well microtiter culture plates and examined with an inverted microscope. By micromanipulation, a single trypomastigote form was isolated and intraperitoneally inoculated into an approximately 8-day-old suckling mouse. From 10 to 30 days after inoculation the peripheral blood was examined for the presence of trypanosomes. They were then defined as clones ${ }^{11}$. Seven clones were isolated by this method and named as: Cl-Col-C1, C2, C3, C4, C5, C6 and C7 respectively. The blood of these mice was inoculated individually into groups of mice with 10 to $12 \mathrm{~g}$ body weight. After 3 to 13 passages into mice, inocula $\left(5 \times 10^{4}\right.$ to $\left.1 \times 10^{5}\right)$ were obtained for the infection of the experimental groups and used for biological, isoenzymic and histopathological characterization of the clones to be compared with the parental strain. One group of mice, having the same body weight, was inoculated with the parental strain for comparison.

Biological characterization - Parasitemia was evaluated on the $7^{\text {th }}$ to $50^{\text {th }}$ day after infection, by microscopic examination of $5 \mathrm{ml}$ of fresh tail blood, between glass and coverslips, and counted in 50 microscopic fields (400X). The parasitemic levels were expressed as logarithms of the media of parasites in peripheral blood of 5 mice.

Cumulative mortality was evaluated from 30 to 50 days after infection. Morphology of trypomastigotes in peripheral blood was evaluated by the percentage of slender and broad forms, as seen in smears stained with the May Grünwald-Giemsa method.

Histopathological study. Three to five infected mice were sacrificed after $14,20,25$ and 30 days post-infection (p.i). Fragments of the myocardium and skeletal muscle were fixed into $10 \%$ formalin and embedded in paraffin. Five-micrometer thick sections were stained with hematoxylin and eosin and microscopically analyzed.

Isoenzymic characterization. Enzymic extracts were obtained by hemoculture in axenic Warren culture medium from each clone. Parasites from culture were washed four times, with centrifugation at $2000 \mathrm{~g}$ in buffer Tris-KRT pH 7.3 and enzymic extracts were prepared and stored in liquid nitrogen as pearls. The following isoenzymes were tested: alanine aminotransferase (ALAT-E.C.2.6.1.2); aspartate aminotransferase (ASAT-E.C.2.6.1.1); glucose-phosphate isomerase (GPI)-E.C.5.3.1.9); phosphoglucomutase (PGM-E.C.2.7.5.1). Electrophoresis was performed according to the method of Miles et $a /^{14}$.

Statiscal analysis. For comparative evaluation of the mortality of mice infected with parental strain and clones a non-parametric Fisher test was applied.

\section{RESULTS}

The biological behavior of the seven clones isolated from the Colombian strain were analyzed in comparison with the parental strain, taking into account several parameters, as follows: parasitemia, morphology of parasite in peripheral blood, cumulative mortality of the infected animals, tissue tropism and histopathological lesions. The parental strain and the seven clones have shown the parasitemic profiles of the Type III strain, with a slow increase in the number of parasites and with peaks of parasitemia between 20 and 30 days p.i. (Figures $1 \mathrm{~A}$ and $\mathrm{B}$ ). By taking the media for 5 mice, the parasitemic peaks were considered as high, above 500 trypomastigotes/50 microscopic fields (400X) or as medium, from 100 to 500 trypomastigotes. The strains with high parasitemic levels determined high mortality rates; medium parasitemic levels, coincided with low mortality. As shown in Table I, the cumulative mortality of mice infected with the parental strain and the seven derived clones, expressed as percentage of dead animals, varied from a low (7.6 to $23 \%$ ) to a high level $(100 \%)$. Mortality up to 30 days of infection was low for the clones $\mathrm{C} 2, \mathrm{C} 5$ and $\mathrm{C} 7$ and high for the parental strain and the clones C1, C3, C4, C6 (100\%). These findings indicate different degrees of virulence for the several clones investigated.

Morphological study of peripheral blood trypomastigotes showed a predominance of slender forms on the $10^{\text {th }}$ day of infection for the parental strain and clones $\mathrm{C} 3, \mathrm{C} 5$ and $\mathrm{C} 7$, and broad forms from the $14^{\text {th }}$ day onwards. The clones C1, C4 and C6 showed a predominance of slender forms up to the $14^{\text {th }}$ day of infection. The parental strain and its 7 clones presented a predominance of broad forms by the $20^{\text {th }}$ day of infection. 

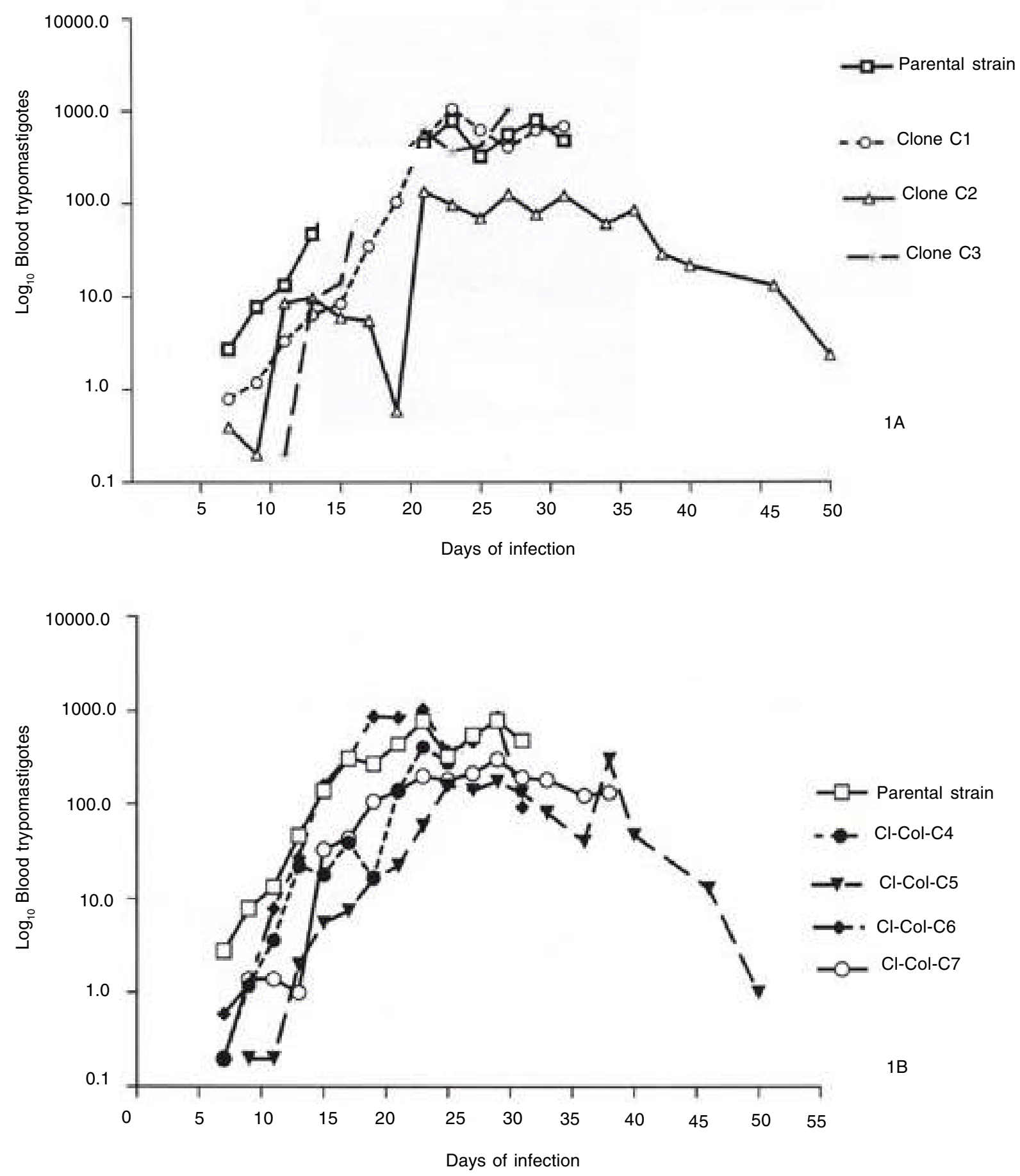

Figure $1 \mathrm{~A}$ and $1 \mathrm{~B}$ - Log mean number of blood trypomastigotes in 50 high power microscopic fields (400X) of 5 mice infected with either the parental Colombian strain or Clones $\mathrm{Cl}-\mathrm{Col}-\mathrm{C} 1, \mathrm{C} 2, \mathrm{C} 3, \mathrm{C4}, \mathrm{C} 5, \mathrm{C} 6, \mathrm{C} 7$. Parasitemic profiles are similar for the seven clones as compared with the parental strain with peaks from 20 to 30 days post-infection. 
Table 1 - Cumulative mortality in mice infected with the Colombian strain of Trypanosoma cruzi and its clones (30 days of infection).

\begin{tabular}{lcccc}
\hline Experimental groups & Inoculum & Mice number & Mortality & Mortality $(\%)$ \\
\hline Parental strain & $1 \times 10^{5}$ & 25 & $9 / 90$ & 100.0 \\
Cl-Col-C1 & $5 \times 10^{4}$ & 18 & $11 / 11$ & 100.0 \\
Cl-Col-C6 & $1 \times 10^{5}$ & 25 & $14 / 14$ & 100.0 \\
Cl-Col-C3 & $5 \times 10^{4}$ & 25 & $12 / 13$ & 92.3 \\
Cl-Col-C4 & $1 \times 10^{5}$ & 25 & $15 / 19$ & 78.9 \\
Cl-Col-C7 & $1 \times 10^{5}$ & 25 & $3 / 13$ & 23.0 \\
Cl-Col-C2 & $1 \times 10^{5}$ & 25 & $1 / 13$ & 7.6 \\
Cl-Col-C5 & $1 \times 10^{5}$ & 25 & $1 / 13$ & 7.6 \\
\hline
\end{tabular}

Comparison of percentage of mortality between clones and parental strain has shown significant differences for clones $\mathrm{C} 7, \mathrm{C} 2, \mathrm{C} 5$ ( $p<0.01$ Fischer test).

Isoenzymic characterization. The electrophoretic patterns obtained for the parental strain and its clones, regarding the enzymes PGM, GPI, ALAT and ASAT, reproduced the profiles already described for the

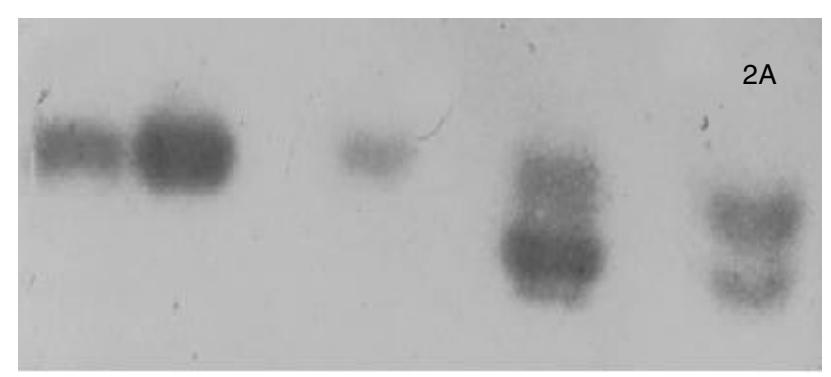

Biodeme Type $\mathrm{III}^{7}$, corresponding to zymodeme $\mathrm{Z}^{14}$ (Figures 2, 3 and 4). Clone $C 1$ revealed 3 bands with the enzyme ALAT (Figure 4A); clone C3 revealed 2 bands with the enzyme ASAT (Figure 4B).

Figure $2 \mathrm{~A}$ and $2 \mathrm{~B}$ - Isoenzymic profiles for PGM of the Colombian parental strain and the clones $\mathrm{Cl}-\mathrm{Col}-\mathrm{C} 3$ and $\mathrm{C} 4$ in comparison with prototypes of Biodemes I (Per), II (21SF), III (Col).
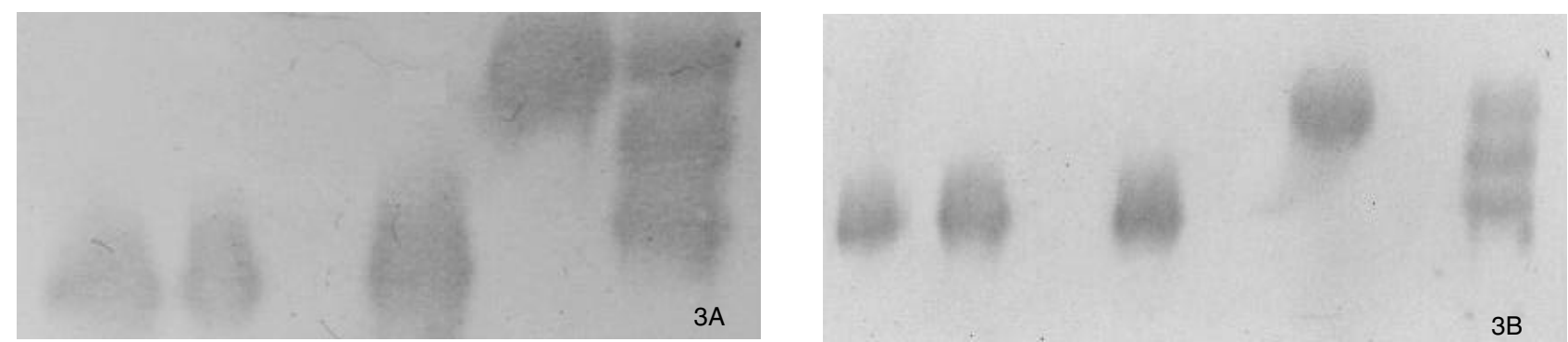

Figure $3 A$ and $3 B$ - Electrophoretic isoenzymic patterns for GPI of the Colombian parental strain and the clones $\mathrm{Cl}-\mathrm{Col}-\mathrm{C} 2$ and $\mathrm{C} 7$ as compared with the Biodemes I, II, III respectively: Per, 21SF, Col.
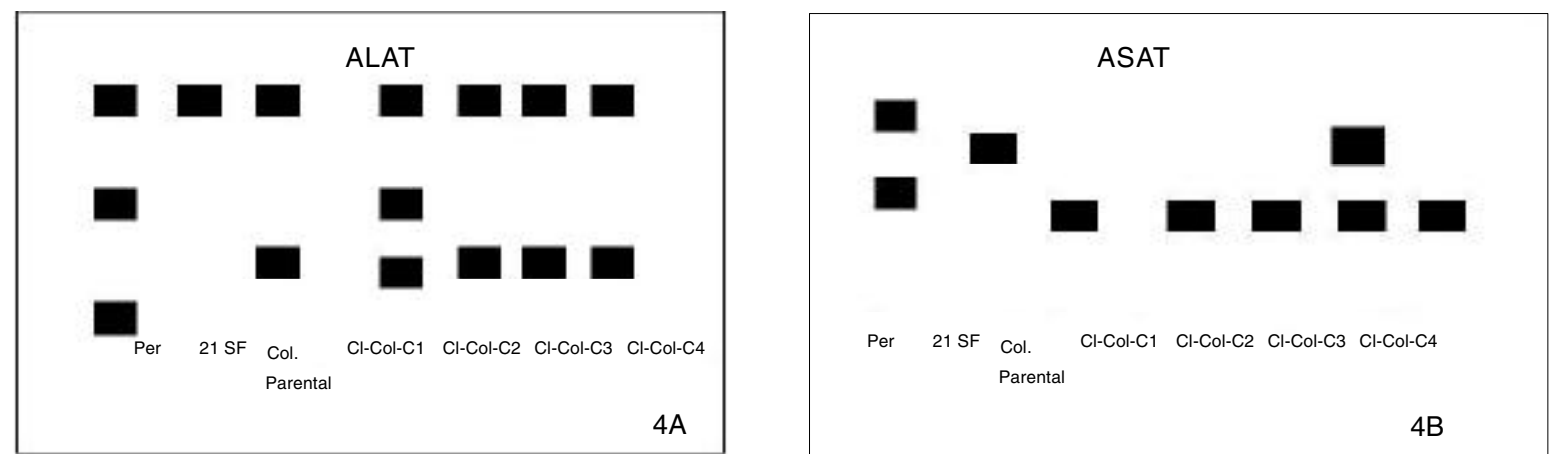

Figure $4 A$ and $4 B$ - Isoenzymic profiles for ALAT and ASAT of the Colombian parental strain and the clones Cl$\mathrm{Col}-\mathrm{C} 1, \mathrm{C} 2, \mathrm{C} 3, \mathrm{C} 4$ in comparison with the prototypes of Biodemes I, II, III. A 3-band profile of ALAT in clone C1 and a 2-band profile for ASAT in clone C3 represent alternative patterns for these enzymes. 
Histopathological study. Study of the tissue lesions and parasite tropism was comparatively performed for the parental strain and its clones. The parental strain determined progressive skeletal muscle and myocardium lesions, from the $14^{\text {th }}$ day of infection, with slight mononuclear infiltration and low parasitism of myocytes. By the $20^{\text {th }}$ day of infection a progressive parasitism of myocardiocytes was seen, with focal myocyte necrosis and diffuse mononuclear-cell infiltration (Figure 5A). Tissue parasitism and destruction of myocells with dense inflammatory infiltration were prominent in skeletal muscles and progressive until 30 days of infection (Figure 5B).
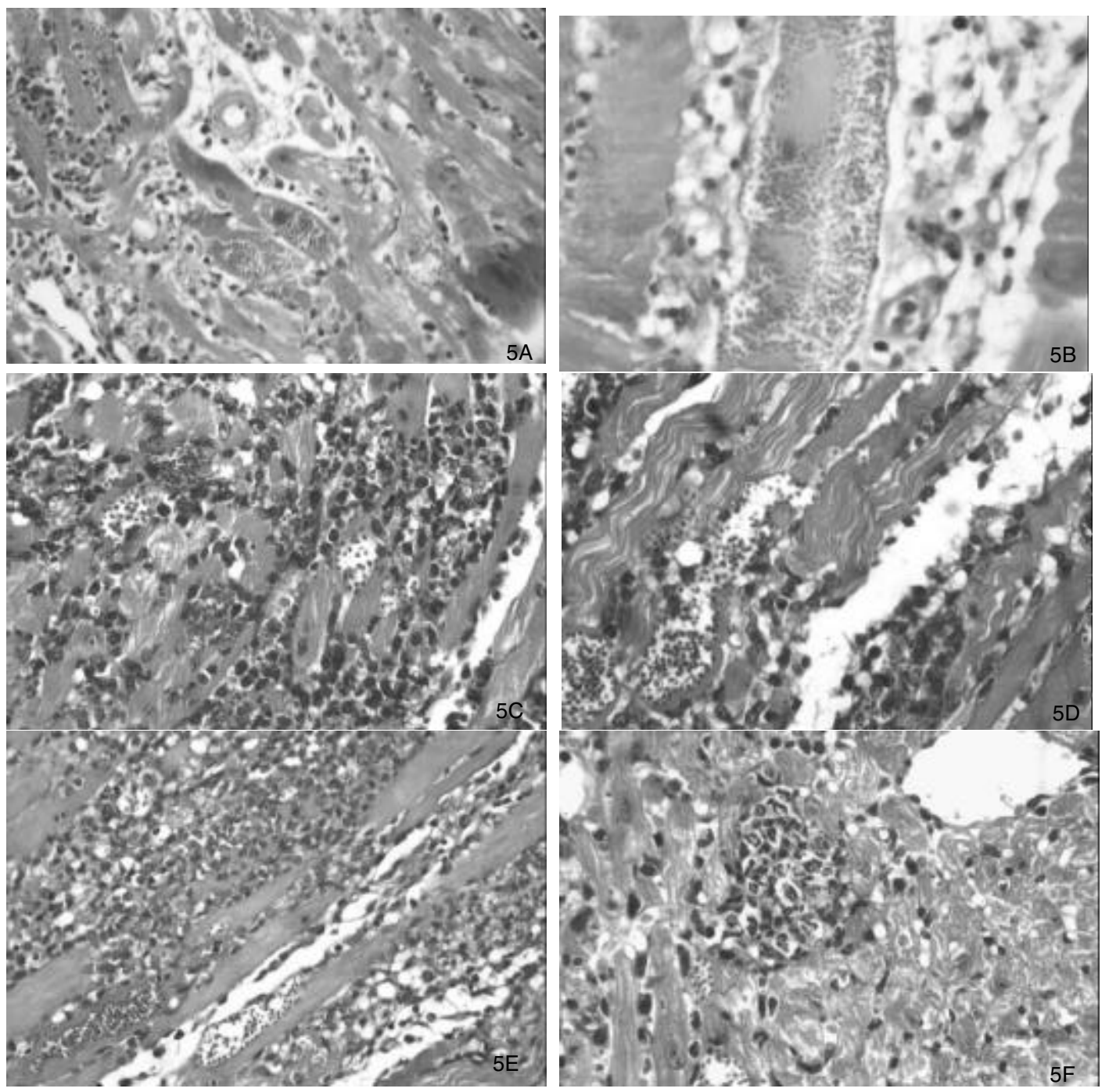

Figure 5A and 5B - Cardiac and skeletal muscle lesions in mice infected with the Colombian parental strain: $\boldsymbol{A}$ - Diffuse and moderate myocarditis and presence of parasites in the cardiac myocytes (250X); $\boldsymbol{B}$-necrosis of skeletal muscle cells with mononuclear infiltrate; presence of a large nest of amastigotes in a damaged skeletal muscle cell $(400 \mathrm{X})$; Figure $\boldsymbol{C}$ and $\boldsymbol{D}$ - Clone Cl-Col-C4: $\boldsymbol{C}$-Intense myocarditis and presence of intracellular parasites in cardiac myocells (250X); $D$ - Skeletal muscle cell with intracellular parasites associated with myocell disintegration and the presence of polyor skeletal muscle with parasite debris and intracellular amastigotes, intense polymorphonuclear and mononuclear inflammatory infiltration (250X); $F-$ myocardium showing intense mononuclear infiltration and the presence of focal disintegration of parasitized myocell with intense polymorphonuclear
infiltration (250X).
Histopathological lesions determined by each one of the seven clones, from 14 to 30 days of infection, showed the same evolution and histopathological aspects of the parental strain. For the seven clones, parasitism and inflammatory infiltration were present at 14 and 20 days p.i., varying from slight to moderate in keeping with the virulence of the clone. Necro-inflammatory lesions were more prominent in skeletal muscles and intensified up to the $30^{\text {th }}$ day of infection. In general, this late phase exhibited parasite and myocell disintegration, together with severe mononuclear-cell infiltration and rare preserved parasites (Figures 5C,D, E and F). 


\section{DISCUSSION}

T. cruzi strains represent multiclonal populations, as described by Tibayrenc et $a^{R 0}$. based on the multiloci isoenzymic profile of 121 strains from different geographical areas. Macedo and Pena ${ }^{13}$ suggest that multiclonal strains are formed by clonally propagating organisms with different tissue tropisms, correlated with complementary molecular interactions between the invading clones of $T$. cruzi and the host tissues. Clonal populations can be homogeneous or heterogeneous. It has been admitted that a limited number of principal clones could be circulating within different geographical areas $^{19}$. The present study has demonstrated a homogeneity of the clones obtained from the Colombian strain, both considering its biological behavior and isoenzymic profiles. On analyzing the behavior of the Colombian strain after long period of maintenance in laboratory, by successive passages into mice, an increased virulence was detected, which was revealed by high mortality up to 30 days of infection. The Colombian strain, as initially described ${ }^{3}$, was characterized by a slow progression of parasitemia, that reached high levels by the $20^{\text {th }}$ to $30^{\text {th }}$ day of infection, with predominance of broad parasite forms from the initial phase of infection and low mortality up to 30 days p.i. Activation of parasite virulence, evaluated in infected mice, either after macrophage blockade with Indian Ink or treatment with corticoid, results in earlier increasing of parasitemia and the presence of slender parasitic forms ${ }^{6}$.

However, considering the profiles of parasitemia, the tissue tropism and pathogenicity pattern, the biological behavior of the Colombian strain was maintained. The seven clones, with the same biological patterns of the parental strain, exhibited different degrees of virulence, as expressed by high levels of parasitemia and elevated mortality; however as has been previously demonstrated $^{1}$, virulence is not a stable character, and therefore cannot independently be used for strain characterization. The same type of strain can present different degrees of virulence, evaluated by the levels of parasitemia and the rate of mortality of infected animals. The several strains isolated from São Felipe, BA classified as Biodeme Type II, could either exhibit low virulence, without mortality by the $20^{\text {th }}$ day of infection; medium virulence, with $50 \%$ mortality or high virulence, with $100 \%$ mortality by 20 days of infection. However, comparative histopathological study revealed that lesions determined by the parental strain and its clones disclosed the same pattern of pathogenicity: same tissue tropism, with predominant involvement of skeletal muscles, intense myocarditis and high tissue parasitism. These findings suggest that when a predominant principal clone is present the histotropism of the strain and of the clones is similar, confirming the stability of strain behavior. The isoenzymic profile of Biodeme Type III represents the same pattern of zymodeme 1 as described by Miles et $a l^{14}$. The isoenzymic patterns for GPI and PGM represent the same profile for the parental strain and clones, representing a homozygosis for these enzymes. However, the presence of a profile of three bands for ALAT in the clone C1 and two bands for ASAT in the clone $\mathrm{C} 3$ represents alternative patterns, as previously demonstrated ${ }^{714}$. According to Miles et $a^{14}$, of the 11 enzymes which did contribute to the separation of the zymodemes, four gave alternative patterns within individual zymodemes; as for ALAT, up to four ancillary, prominent bands were seen in zymodeme $1(Z !)^{14}$; and ASAT has been described with one or two bands, for $Z 1^{714}$.

The present results, indicative of homogeneity for the clones isolated from the Colombian strain, support the suggestion that the presence of a principal clone may be influencing the behavior of Type III strains that circulate in a given endemic area. The predominance of the same type of strain has been recently confirmed by Rodriguez et $a 1^{16}$, studying 13 strains from Colombia, and showing that all of them belong to zymodeme $\mathrm{Z} 1$ and conform only one cluster by analysis of the dendogram.

The zymodeme $\mathrm{Z} 1$ is recognized as representing a sylvatic origin of the parasite ${ }^{8}$ but with presence in the domestic environments. Humans infected with this type of strain have already been identified ${ }^{5}$, and this can influence clinico-pathological manifestations and therapeutic responses in Chagas' disease patients, in endemic areas where sylvatic reservoirs or vectors occur. Resistance to chemotherapy observed with the parental strain is shared by each of its clones, as seen in recent studies (in publication). This seems to confirm the clonal homogeneity of the Colombian strain and its influence in the response to treatment, at least when the isolation of clones is performed around the $30^{\text {th }}$ day p.i. The possibility of monoclonallity could not be disproved, but the isolation of a limited number of clones could not confirm the absence of different clones not revealed with the technical approaches used in this study.

This does not preclude that different results could be obtained if the isolation of the clones was performed during an earlier phase of the infection. In this sense, new investigations are in course, with the objective of analyzing clones of Type III strains, obtained in the initial phase of infection and to test their sensibility to chemotherapeutics.

The findings of the present study point to an important role of the parasite strain in the course of infection in the vertebrate host, taking into account the predominance of a principal clone with a marked tissular tropism and high pathogenicity and resistance to chemotherapy. This could be responsible for severity of acute illness or explain chronic disease manifestations in patients infected with this type of strain, identified as of sylvatic origin, and corresponding to the proposed taxa T. cruzi I' 


\section{REFERENCES}

1. Andrade SG. Caracterização de cepas do Trypanosoma cruzi isoladas Recôncavo baiano (Contribuição ao estudo da patologia geral da doença de Chagas em nosso meio). Revista de Patologia Tropical 3:65-121, 1974.

2. Andrade SG. Trypanosoma cruzi: clonal structure of parasites strains and the importance of principal clones. Memórias do Instituto Oswaldo Cruz 94 (supl I): 185-187, 1999.

3. Andrade SG, Carvalho ML, Figueira RM. Caracterização morfobiológica e histopatológica de diferentes cepas do Trypanosoma cruzi. Gazeta Médica da Bahia 70:32-42, 1970.

4. Andrade SG, Magalhães JB, Pontes AL. Evaluation of chemotherapy with benzonidazole and nifurtimox in mice infected with Trypanosoma cruzi strains of different types. Bulletin of the World Health Organization 63:721-726, 1985.

5. Andrade SG, Rassi A, Magalhães JB, Ferriolli Filho F, Luquetti, AO. Specific chemotherapy of Chagas' disease: a comparison between the response in patients and experimental animals inoculated with the same strains. Transaction of the Royal Society of Tropical Medicine and Hygiene 86:624-626, 1992.

6. Andrade SG, Silva AA, Carvalho ML, Figueira, RM. Comportamento de uma cepa do Trypanosoma cruzi em hospedeiros de baixa resistência. Revista do Instituto de Medicina Tropical de São Paulo 14:154-161, 1972.

7. Andrade V, Brodskyn C, Andrade SG. Correlation between isoenzyme patterns and biological behaviour of different strains of Trypanosoma cruzi. Transaction of the Royal Society of Tropical Medicine and Hygiene 77:796-799, 1983.

8. Barrett TV, Hoff RH, Mott KE, Miles MA, Godfrey DG, Teixeira R, Almeida Souza JAA, Sherlock IA. Epidemiological aspects of three Trypanosoma cruzi zymodemes in Bahia State, Brasil. Transaction of the Royal Society of Tropical Medicine and Hygiene 74:84-90, 1980.

9. Campos RMF, Andrade SG. Characterisation of subpopulations (clones and subclones) of the 21 SF strain of Trypanosoma cruzi after long lasting maintenance in the laboratory. Memórias do Instituto Oswaldo Cruz 91:795-800, 1996.

10. Campos RMF, Gonçalves MS, Reis EAG, Reis MG, Andrade SG. $C$ omparative analysis by polymerase chain reaction ampliflied minicircles of kinetoplast DNA of a stable strain of Trypanosoma cruzi from São Felipe, Bahia, its clones and subclones: possibility of predominance of a principal clone in this area. Memórias do Instituto Oswaldo Cruz 94:23-29, 1996.

11. Dvorak JA. Single cell isolates of Trypanosoma cruzi: How and Why? Revista da Sociedade Brasileira de Medicina Tropical 18 (supl):29-38, 1985.

12. Federici EE, Abelman WB, Neva FA. Chronic and progressive myocarditis and myositis in $\mathrm{C} 3 \mathrm{H}$ mice infected with Trypanosoma cruzi. The American Journal of Tropical Medicine and Hygiene 13:272-280, 1964.

13. Macedo AM, Pena SDJ. Genetic variability of Trypanosoma cruzi : implications for the pathogenesis of Chagas' disease. Parasitology Today 14:119-123, 1998.

14. Miles MA, Lanham SM, Souza AA, Póvoa M. Further enzymic characters of Trypanosoma cruzi and their evaluation for strain identification. Transaction of the Royal Society of Tropical Medicine and Hygiene 74:221-237, 1980.

15. Momem H. Taxonomy of Trypanosoma cruzi: a commentary on characterization and nomenclature. Memórias do Instituto Oswaldo Cruz 94:181-184, 1999.

16. Rodriguez P, Montilla M, Nicholls S, Zarante I, Puerta C. Isoenzymatic Characterization of Colombian Strains of Trypanosoma cruzi. Memórias do Instituto Oswaldo Cruz 93:739-740, 1998.

17. Silva LHP, Nussenzweig V. Sobre uma cepa de Trypanosoma cruzi altamente virulenta para o camundongo branco. Folia Clinica et Biologica 20:191-208, 1953.

18. Tibayrenc M, Ayala FJ. Isozymic variability in Trypanosoma cruzi, the agent of Chagas' disease: genetical, taxonomical, and epidemiological significance. Evolution 42:277-292, 1988.

19. Tibayrenc M, Brenière SF. Trypanosoma cruzi: major clones rather than zymodemes. Memórias do Instituto Oswaldo Cruz 83(supl 1): 249-255, 1988.

20. Tibayrenc M, Ward P, Moya A, Ayala FJ. Natural populations of Trypanosoma cruzi, the agent of Chagas' disease, have a complex multiclonal structure. Proceedings of the National Academy of Science of USA 83:115-119, 1986. 